\title{
Some Aspects on Knowledge Representation for Geological Exploration*
}

\author{
Xuanzhi WU** and Danian SHI**
}

\begin{abstract}
Knowledge representation is still one of the KEY problems to the success of a practical expert system for geological exploration. Three aspects are discussed in this paper: (a) syntheticuncertain-inference-model instead of a single inference model is more suitable for describing greatly diverse domain expert's knowledge; (b) strong correlation is often a basic feature among pieces of geological evidence, and can be directly treated under a new form of Bayesian model; (c) inversion of parameters describing knowledge makes knowledge engineering much easier. Finally, a prototype system expressing the above ideas is presented.
\end{abstract}

Key Words : Artificial Intelligence, Expert system, Knowledge representation, Uncertainty reasoning, Dependent evidence, Confirmation factor, Geological exploration, Supergene deposit.

\section{Introduction}

The power of an expert system rests upon a knowledge base that puts together factual information about the domain and the heuristic "rules of thumb" which experts use to rapidly find solutions to problems. The key to success of a practical expert system is that the knowledge encoded in the system reflects exactly the real world of the problem expected to be solved with this system. Since we are relying on opinions of genuinely knowledgeable experts, the problem we face now is how for knowledge engineers to express expert's knowledge in their system.

Management of uncertainty is at the heart of the problem. A number of approaches have been developed for dealing with this issue. Historically, probability has been by far the most widely used formalism for representing uncertainty. However, the majority of AI researchers have difficulties in using standard probabilistic techniques in rule-based expert systems. Among the many alternative numerical schemes for quantifying uncertainty that have been developed are the Certainty Factor used in the MYCIN (Shortliffe and Buchanan, 1984), the Fuzzy set theory (Zadeh, 1984), the quasi-probabilistic scheme of the PROSPECTOR (Duda et al., 1976, 1979), and the Belief functions of the Dempster-Shafer theory (Shafer, 1976, 1987). Each of these techniques has its partisans and detractors, and the debate about their various merits and drawbacks still seems to be hot (Shafer, 1981; Lee, 1988; Cui and Blockly,

* Orally presented at International Symposium on Mineral Exploration: -The Use of Artificial Intelligence, 1990 (ISME-AI '90, Tokyo and Tsukuba)

** Institute of Mineral Deposits, Chinese Academy of Geological Sciences, 26 Baiwanzhuang, Beijing, 100037, China
1990; Kyburg, 1987; Fagin and Halpern, 1989; Henrion, 1986).

We do not intend to be involved in the debate even though most of our encoded knowledge is expressed in an inference rule of an IF-THEN type and the representation of uncertainty is in terms of Bayesian probabilities. We argue that a natural way to describe expert's knowledge is to utilize the form that experts use. It is our point that an intelligent system could be viewed as a descriptive model of the expert reasoning process and the knowledge engineer would be better off to follow the domain experts' train of thought rather than to ask the expert to fit his knowledge to a specific frame. We believe that it may be a good policy, at least at present, to follow an expertfriendly principle and select one of the known inference-models or to create some new one, if necessary, for properly describing a certain piece of expert's knowledge.

Three aspects are discussed below. In the first section we argue that a synthetic-uncertain-inferencemodel instead of a single inference model is more suitable for us to express diverse geological exploration knowledge. Next we describe a new form of Bayesian model for uncertainty propagation and propose an empirical expression of the aggregate updating with dependent evidence. In Section 4, we present an algorithm for inversion of parameters representing degree of dependence between pieces of evidence. Finally, we show a prototype system expressing the above ideas.

\section{Synthetic-Uncertain-Inference-Model}

It is usually accepted by geological exploration experts that their knowledge can be expressed in an inference network. Most inference networks in geological exploration are almost hierarchical. Expert's 
knowledge of geological exploration contains the inference network and the description of the connection (arc, or rule) between the root node or intermediate nodes and their immediate descendant nodes. The controversy is over the latter. We accept most of the better known numerical models (see Section 5 for details) in our system as candidates of an inference model for expressing certainty arcs. The Bayesian model is the most widely used and the DempsterShafer model is referred to as a promising one. The MYCIN performs impressively indeed despite its inconsistent use of measures of certainty (Horitz and Hecherman, 1986). In fact, a formal study demonstrated that the MYCIN was quite insensitive to the precision of the numbers used for certainty factors (Victor et al., 1984). We expect that the MYCIN model may also well express some propositions in the geological exploration domain or be favored by some geological experts who defy the requirement of the prior probabilities of events in inference networks for Bayesian uncertainty updating. Concerning such an idea, the definition of an arc should become part of the attributes of nodes. When knowledge is represented by a frame, the inference model describing the arc is one of the slots of the frame. Different arcs can be specified with different inference models and the inference engine of the expert system only contains a reasoning control strategy. Each step of uncertainty updating should follow the definition of the inference model specified to the node under consideration. Here is an example;

If $\mathrm{B}_{1}$ then $\mathrm{A}, \mathrm{MYC}, \mathrm{CF}\left(\mathrm{A} \mid \mathrm{B}_{1}\right)$.

If $\mathrm{B}_{2}$ then $\mathrm{A}, \mathrm{MYC}, \mathrm{CF}\left(\mathrm{A} \mid \mathrm{B}_{2}\right)$.

If $\mathrm{C}_{1}$ then $\mathrm{B}_{1}, \mathrm{BYS}, \mathrm{C}\left(\mathrm{B}_{1} \mid \mathrm{C}_{1}\right), \mathrm{C}\left(\mathrm{B}_{1} \mid \tilde{\mathrm{C}}_{1}\right), \mathrm{P}\left(\mathrm{B}_{1}\right)$.

If $\mathrm{C}_{2}$ then $\mathrm{B}_{1}, \mathrm{BYS}, \mathrm{C}\left(\mathrm{B}_{1} \mid \mathrm{C}_{2}\right), \mathrm{C}\left(\mathrm{B}_{1} \mid \tilde{\mathrm{C}}_{2}\right), \mathrm{P}\left(\mathrm{B}_{1}\right)$.

If $\mathrm{C}_{3}$ or $\mathrm{C}_{4}$ then $\mathrm{B}_{2}, \mathrm{MAX}-\mathrm{OR}$.

where MYC, BYS and MAX-OR represent the MYCIN model, the Bayesian model and maximum-correlation disjunction respectively. The parameters $\mathrm{C}$ $\left(\mathrm{B}_{1} \mid \mathrm{C}_{1}\right), \mathrm{C}\left(\mathrm{B}_{1} \mid \tilde{\mathrm{C}}_{1}\right)$ are confirmation factors of our new form of Bayesian model which are equivalent to

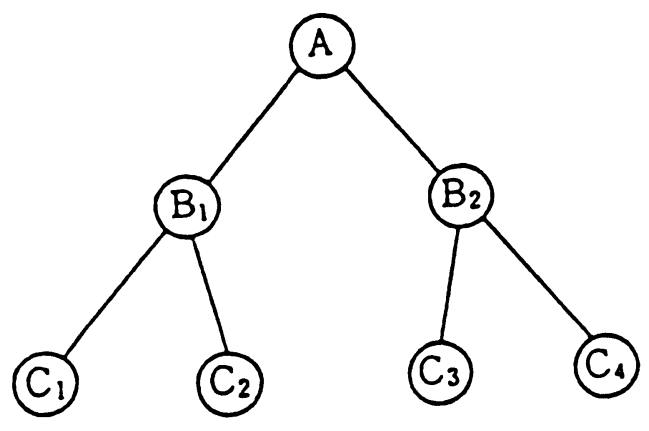

Fig. 1. Example of synthetic inference the likelihood LS and LN (discussed later) in the conventional form. A problem is the transformation of the parameters between different inference models. The parameters involved are the uncertainty degree, which is the certainty factor belonging to $[-1,1]$ in the MYCIN model, the degree of belief belonging to $[-5,5]$ in the Bayesian model, the belief and likelihood interval in the Dempster-Shafer model, and the probability value in the evidence conjunction or disjunction method. Fortunately, the certainty factor in the MYCIN model is the same as that in our new Bayesian model, and is equal to the degree of belief in the conventional Bayesian model divided by 5 . They can transform into probabilities by the equation :

$$
\mathrm{P}\left(\mathrm{H} \mid \mathrm{E}^{\prime}\right)= \begin{cases}\mathrm{P}(\mathrm{H})+\mathrm{P}(\tilde{\mathrm{H}}) \mathrm{C}\left(\mathrm{H} \mid \mathrm{E}^{\prime}\right), & \text { if } \mathrm{C}\left(\mathrm{H} \mid \mathrm{E}^{\prime}\right) \geqq 0 \\ \mathrm{P}(\mathrm{H})+\mathrm{P}(\mathrm{H}) \mathrm{C}\left(\mathrm{H} \mid \mathrm{E}^{\prime}\right), & \text { if } \mathrm{C}\left(\mathrm{H} \mid \mathrm{E}^{\prime}\right)<0\end{cases}
$$

The transformation of a real probability into an interval, and vice verse, can be defined respectively as:

$$
\begin{aligned}
& \mathrm{P}_{1} \longrightarrow\left(\mathrm{P}_{1}, \mathrm{P}_{1}\right) \\
& \left(\mathrm{P}_{2}, \mathrm{P}_{3}\right) \longrightarrow\left(\mathrm{P}_{2}+\mathrm{P}_{3}\right) / 2
\end{aligned}
$$

\section{New Form of the Bayesian Model and Aggregate Belief Updating due to Dependent Evidence}

It is very common that pieces of geological evidence are strongly correlated each other. In an integrated information model of geological exploration, different types of information share a common source. They usually appear simultaneously, and are correlated strongly. For technical or economic reasons, geologists usually obtain only part of them and have to carry on their inference process with such information. The rules based on individual types of evidence are fundamental. The strength of the compound rules should be defined by combining constituent rules in some way, taking the correlation between pieces of evidence into account.

This difficult problem is usually avoided in many schemes of reasoning by explicitly or implicitly making liberal use of assumptions concerning conditional independence, or, more generally, invoking the maximum entropy principle. An unsatisfactory feature of such an approach is that it yields results based on assumptions that may not be valid. Furthermore, there are two more interesting cases in geological exploration.

Case A: the certainty of a hypothesis due to evidence $\mathrm{E}_{j}$ given evidence $\mathrm{E}_{i}$ increases much more greatly than that in the case of $\mathrm{E}_{i}$ and $\mathrm{E}_{j}$ being independent each other.

Case $\mathrm{B}$ : the coexistence of $\mathrm{E}_{i}$ and $\mathrm{E}_{j}$ rejects the hypothesis whereas each piece of evidence individual- 
ly confirms the hypothesis.

There is no harmonious way for the known uncertainty updating schemes to express these rules of belief updating.

Before suggesting an algorithm for aggregate belief updating in light of dependent evidence we describe a new form of Bayesian model. The purpose of introducing a new form of Bayesian model is to limit, at least as far as possible, the requirement of $a$ priori probability of each event, and also to find a favorable form for expressing the effect of correlation between pieces of evidence on the belief of their consequence.

Let us first quote the fundamental equations of the Odds-Likelihood form of Bayesian model (Duda $e t$ al., 1979):

$$
\begin{aligned}
& \mathrm{O}(\mathrm{H} \mid \mathrm{E})=\mathrm{LS}(\mathrm{H} \mid \mathrm{E}) * \mathrm{O}(\mathrm{H}) \\
& \mathrm{O}(\mathrm{H} \mid \tilde{\mathrm{E}})=\mathrm{LN}(\mathrm{H} \mid \mathrm{E}) * \mathrm{O}(\mathrm{H})
\end{aligned}
$$

where

LS $(H \mid E)=\frac{P(E \mid H)}{P(E \mid \tilde{H})}$, the degree of sufficiency

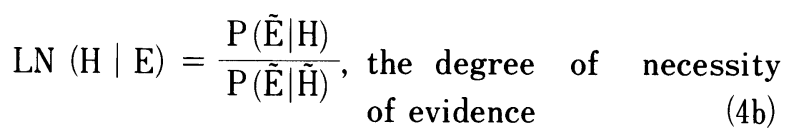

$$
\mathrm{O}(\mathrm{H})=\frac{\mathrm{P}(\mathrm{H})}{1-\mathrm{P}(\mathrm{H})}, \quad \text { the Odds of } \mathrm{H}
$$

If the evidence, E' that results from a survey or by implication from its immediate descendant nodes, is also uncertain, then the problem of propagation of uncertainty could be resolved by using the following rule:

$$
\mathrm{P}\left(\mathrm{H} \mid \mathrm{E}^{\prime}\right)=\mathrm{P}(\mathrm{H} \mid \mathrm{E}) \mathrm{P}\left(\mathrm{E} \mid \mathrm{E}^{\prime}\right)+\mathrm{P}(\mathrm{H} \mid \tilde{\mathrm{E}}) \mathrm{P}\left(\tilde{\mathrm{E}} \mid \mathrm{E}^{\prime}\right) \text {, }
$$

which is directly deduced under the assumptions

$$
\mathrm{P}(\mathrm{H} \mid \mathrm{EE})=\mathrm{P}(\mathrm{H} \mid \mathrm{E}) \text { and } \mathrm{P}\left(\mathrm{H} \mid \tilde{\mathrm{E}} \mathrm{E}^{\prime}\right)=\mathrm{P}(\mathrm{H} \mid \tilde{\mathrm{E}}) \text {. }
$$

The solution should also satisfy another rule:

$$
\mathrm{P}\left(\mathrm{H} \mid \mathrm{E}^{\prime}\right)=\mathrm{P}(\mathrm{H}) \text {, if } \mathrm{P}\left(\mathrm{E} \mid \mathrm{E}^{\prime}\right)=\mathrm{P}(\mathrm{E}) \text {. }
$$

Therefore, an approximation of $\mathrm{P}\left(\mathrm{H} \mid \mathrm{E}^{\prime}\right)$ by two linear interpolations is suggested and it is expressed as:

$$
P\left(H \mid E^{\prime}\right)= \begin{cases}P(H)+(P(H \mid E)-P(H)) & \frac{P\left(E \mid E^{\prime}\right)-P(E)}{1-P(E)} \\ \text { if } \quad P\left(E \mid E^{\prime}\right)>P(E) & \text { if } P\left(E \mid E^{\prime}\right)=P(E) \\ P(H)+(P(H)-P(H \mid \tilde{E})) * \frac{P\left(E \mid E^{\prime}\right)-P(E)}{P(E)} \\ \text { if } P\left(E \mid E^{\prime}\right)<P(E)\end{cases}
$$

In this paper, we will use this approximation (5) of $\mathrm{P}\left(\mathrm{H} \mid \mathrm{E}^{\prime}\right)$. And without loss of generality of our conclusions, we assume every piece of evidence supports its consequence.

We represent the confirmation factor of evidence $\mathrm{E}_{j}$ for $\mathrm{E}_{i}$, or $\mathrm{E}_{i} \mid \mathrm{E}_{j}$, as $\mathrm{C}\left(\mathrm{E}_{i} \mid \mathrm{E}_{j}\right)$ and define:

$\mathrm{C}\left(\mathrm{E}_{i} \mid \mathrm{E}_{j}\right)=\left\{\begin{array}{lll}\frac{\mathrm{P}\left(\mathrm{E}_{i} \mid \mathrm{E}_{j}\right)-\mathrm{P}\left(\mathrm{E}_{i}\right)}{1-\mathrm{P}\left(\mathrm{E}_{i}\right)}, & \text { if } & \mathrm{P}\left(\mathrm{E}_{i} \mid \mathrm{E}_{j}\right)>\mathrm{P}\left(\mathrm{E}_{i}\right) \\ \frac{0,}{\mathrm{P}\left(\mathrm{E}_{i} \mid \mathrm{E}_{j}\right)-\mathrm{P}\left(\mathrm{E}_{i}\right)} & \text { if } & \mathrm{P}\left(\mathrm{E}_{i} \mid \mathrm{E}_{j}\right)=\mathrm{P}\left(\mathrm{E}_{i}\right) \\ \mathrm{P}\left(\mathrm{E}_{i}\right) & \text { if } & \mathrm{P}\left(\mathrm{E}_{i} \mid \mathrm{E}_{j}\right)>\mathrm{P}\left(\mathrm{E}_{i}\right)\end{array}\right.$

Eq.(5) becomes

$\mathrm{C}\left(\mathrm{H} \mid \mathrm{E}^{\prime}\right)=\left\{\begin{array}{lll}\mathrm{C}(\mathrm{H} \mid \mathrm{E}) * \mathrm{C}\left(\mathrm{E} \mid \mathrm{E}^{\prime}\right), & \text { if } & \mathrm{C}\left(\mathrm{E} \mid \mathrm{E}^{\prime}\right)>0 \\ 0, & \text { if } & \mathrm{C}\left(\mathrm{E} \mid \mathrm{E}^{\prime}\right)=0 \\ -\mathrm{C}(\mathrm{H} \mid \tilde{\mathrm{E}}) * \mathrm{C}\left(\mathrm{E} \mid \mathrm{E}^{\prime}\right), & \text { if } & \mathrm{C}\left(\mathrm{E} \mid \mathrm{E}^{\prime}\right)<0\end{array}\right.$

$\mathrm{Eq} .(7)$ is the rule of uncertainty propagation for cascade reasoning. It is equivalent to the Odds-Likelihood form of the Bayesian model. $\mathrm{C}(\mathrm{H} \mid \mathrm{E})>0$ means that the evidence $\mathrm{E}$ increases belief of hypothesis $\mathrm{H}$, and $\mathrm{C}(\mathrm{H} \mid \mathrm{E})=1$ means that $\mathrm{E}$ is a sufficient condition for $\mathrm{H}, \mathrm{C}(\mathrm{H} \mid \tilde{\mathrm{E}})=-1$ means that the absence of evidence $\mathrm{E}$ completely rejects the hypothesis $\mathrm{H}$, so that $\mathrm{E}$ is the absolutely necessary condition for $\mathrm{H}$. $\mathrm{C}(\mathrm{H} \mid \mathrm{E})=0$ means that $\mathrm{H}$ is independent of $\mathrm{E}$. Obviously, giving $\mathrm{C}(\mathrm{H} \mid \mathrm{E})$ and $\mathrm{C}(\mathrm{H} \mid \tilde{\mathrm{E}})$ is equivalent to giving $\mathrm{LS}(\mathrm{H} \mid \mathrm{E})$ and $\mathrm{LN}(\mathrm{H} \mid \mathrm{E})$. In fact, we have:

$$
\begin{aligned}
& \left\{\begin{array}{l}
\mathrm{C}(\mathrm{H} \mid \mathrm{E})=\frac{(\mathrm{LS}(\mathrm{H} \mid \mathrm{E})-1) \mathrm{P}(\mathrm{H})}{(\mathrm{LS}(\mathrm{H} \mid \mathrm{E})-1) \mathrm{P}(\mathrm{H})+1} \\
\mathrm{C}(\mathrm{H} \mid \tilde{\mathrm{E}})=\frac{(\mathrm{LN}(\mathrm{H} \mid \mathrm{E})-1) \mathrm{P}(\tilde{\mathrm{H}})}{(\mathrm{LN}(\mathrm{H} \mid \mathrm{E})-1) \mathrm{P}(\mathrm{H})+1}
\end{array}\right. \\
& \left\{\begin{array}{l}
\mathrm{LS}(\mathrm{H} \mid \mathrm{E})=\frac{\mathrm{P}(\mathrm{H})+\mathrm{P}(\tilde{\mathrm{H}}) \mathrm{C}(\mathrm{H} \mid \mathrm{E})}{\mathrm{P}(\mathrm{H})(1-\mathrm{C}(\mathrm{H} \mid \mathrm{E}))} \\
\mathrm{LN}(\mathrm{H} \mid \mathrm{E})=\frac{\mathrm{P}(\tilde{\mathrm{H}})(1+\mathrm{C}(\mathrm{H} \mid \tilde{\mathrm{E}}))}{1-\mathrm{P}(\mathrm{H})(1+\mathrm{C}(\mathrm{H} \mid \tilde{E}))}
\end{array}\right.
\end{aligned}
$$

and

$$
\mathrm{P}\left(\mathrm{H} \mid \mathrm{E}^{\prime}\right)= \begin{cases}\mathrm{P}(\mathrm{H})+\mathrm{P}(\tilde{\mathrm{H}}) \mathrm{C}\left(\mathrm{H} \mid \mathrm{E}^{\prime}\right), & \text { if } \mathrm{C}\left(\mathrm{H} \mid \mathrm{E}^{\prime}\right) \geqq 0 \\ \mathrm{P}(\mathrm{H})+\mathrm{P}(\mathrm{H}) \mathrm{C}\left(\mathrm{H} \mid \mathrm{E}^{\prime}\right), & \text { if } \mathrm{C}\left(\mathrm{H} \mid \mathrm{E}^{\prime}\right)<0\end{cases}
$$

$\mathrm{Eq}$. (7) shows that in cascade reasoning, we need not know the a priori probability $\mathrm{P}(\mathrm{H}) . \mathrm{C}\left(\mathrm{H} \mid \mathrm{E}^{\prime}\right)>0$ suggests that the conclusion is believable, the closer to $1 \mathrm{C}\left(\mathrm{H} \mid \mathrm{E}^{\prime}\right)$ is, the more certain the conclusion is. In contrast, $\mathrm{C}\left(\mathrm{H} \mid \mathrm{E}^{\prime}\right)=-1$ means that the hypothesis has to be completely rejected according to the evidence E'.

Now we have a new form of Bayesian model, the certainty-confirmation form of Bayesian model. In this model the strength of the rule is represented by a pair of parameters: the confirmation factor of presence of evidence $\mathrm{C}(\mathrm{H} \mid \mathrm{E})$ and the (dis) confirmation 
factor of absence of evidence $\mathrm{C}(\mathrm{H} \mid \tilde{\mathrm{E}})$. All of the uncertainties of events in an inference network are initialized to zero. After a client provides estimated uncertainties of input nodes, the uncertainty propagates upwards by Eq.(7).

There is a restraint relation between $\mathrm{C}(\mathrm{H} \mid \mathrm{E})$ and $\mathrm{C}(\mathrm{H} \mid \tilde{\mathrm{E}})$. According to the total probability equation,

$$
\mathrm{P}\left(\mathrm{E}_{i}\right)=\mathrm{P}\left(\mathrm{E}_{j}\right) \mathrm{P}\left(\mathrm{E}_{i} \mid \mathrm{E}_{j}\right)+\mathrm{P}\left(\tilde{\mathrm{E}}_{j}\right) \mathrm{P}\left(\mathrm{E}_{i} \mid \tilde{\mathrm{E}}_{j}\right),
$$

and by the definition of $\mathrm{C}(\mathrm{H} \mid \mathrm{E})$, we have

$$
\mathrm{P}(\mathrm{H} \mid \tilde{\mathrm{E}})=(\mathrm{P}(\mathrm{H})-\mathrm{P}(\mathrm{E}) \mathrm{P}(\mathrm{H} \mid \mathrm{E})) / \mathrm{P}(\tilde{\mathrm{E}})
$$

After some manipulation we get:

$$
\mathrm{C}(\mathrm{H} \mid \tilde{\mathrm{E}})=-\frac{\mathrm{O}(\mathrm{E})}{\mathrm{O}(\mathrm{H})} \mathrm{C}(\mathrm{H} \mid \mathrm{E})
$$

So the expert, while he assigns $\mathrm{C}(\mathrm{H} \mid \mathrm{E})$ and $\mathrm{C}(\mathrm{H} \mid \tilde{\mathrm{E}})$, implies the ratio of $\mathrm{O}(\mathrm{E})$ to $\mathrm{O}(\mathrm{H})$, and the relation between $\mathrm{P}(\mathrm{E})$ and $\mathrm{P}(\mathrm{H})$. In geological exploration, the prior probabilities of events are usually closed to zero and the ratio of $\mathrm{O}(\mathrm{E})$ to $\mathrm{O}(\mathrm{H})$ is approximated by the ratio of $\mathrm{P}(\mathrm{E})$ to $\mathrm{P}(\mathrm{H})$.

When the same conclusion is established by a number of different IF-THEN inference rules, how do we aggregate the multiple confirmation factors produced by these rules into a total confirmation factor for this conclusion?

First we consider the case when two pieces of evidence are conditionally independent each other. Following Duda et al. (1976), we have

$$
\mathrm{O}\left(\mathrm{H} \mid \mathrm{E}_{i}{ }^{\prime} \mathrm{E}_{j}{ }^{\prime}\right)=\frac{\mathrm{P}\left(\mathrm{E}_{i}{ }^{\prime} \mid \mathrm{H}\right) \mathrm{P}\left(\mathrm{E}_{j}{ }^{\prime} \mid \mathrm{H}\right)}{\mathrm{P}\left(\mathrm{E}_{i} \mid \tilde{\mathrm{H}}\right) \mathrm{P}\left(\mathrm{E}_{j}{ }^{\prime} \mid \tilde{H}\right)} \mathrm{O}(\mathrm{H})
$$

which after some manipulation gives,

$$
\begin{aligned}
& \mathrm{C}\left(\mathrm{H} \mid \mathrm{E}_{i} \mathrm{E}_{j}\right) \\
& =\frac{\mathrm{P}(\mathrm{H})\left(\mathrm{C}\left(\mathrm{H} \mid \mathrm{E}_{i}\right)+\mathrm{C}\left(\mathrm{H} \mid \mathrm{E}_{j}\right)\right)+(\mathrm{P}(\tilde{\mathrm{H}})-\mathrm{P}(\mathrm{H})) \mathrm{C}\left(\mathrm{H} \mid \mathrm{E}_{i}\right) \mathrm{C}\left(\mathrm{H} \mid \mathrm{E}_{j}\right)}{\mathrm{P}(\mathrm{H})+\mathrm{P}(\tilde{\mathrm{H}}) \mathrm{C}\left(\mathrm{H} \mid \mathrm{E}_{i}\right) \mathrm{C}\left(\mathrm{H} \mid \mathrm{E}_{j}\right)}
\end{aligned}
$$

$\mathrm{C}\left(\mathrm{H} \mid \tilde{\mathrm{E}}_{i} \tilde{\mathrm{E}}_{j}\right)$

$$
=\frac{\mathrm{P}(\tilde{\mathrm{H}})\left(\mathrm{C}\left(\mathrm{H} \mid \tilde{\mathrm{E}}_{i}\right)+\mathrm{C}\left(\mathrm{H} \mid \tilde{\mathrm{E}}_{j}\right)\right)+(\mathrm{P}(\tilde{\mathrm{H}})-\mathrm{P}(\mathrm{H})) \mathrm{C}\left(\mathrm{H} \mid \tilde{\mathrm{E}}_{i}\right) \mathrm{C}\left(\mathrm{H} \mid \tilde{\mathrm{E}}_{j}\right)}{\mathrm{P}(\tilde{\mathrm{H}})+\mathrm{P}(\mathrm{H}) \mathrm{C}\left(\mathrm{H} \mid \tilde{\mathrm{E}}_{i}\right) \mathrm{C}\left(\mathrm{H} \mid \tilde{\mathrm{E}}_{j}\right)}
$$

$$
\mathrm{C}\left(\mathrm{H} \mid \mathrm{E}_{i} \tilde{\mathrm{E}}_{j}\right)=\left\{\begin{array}{l}
\frac{\mathrm{DLT}}{\mathrm{P}(\tilde{\mathrm{H}})\left(1+\mathrm{C}\left(\mathrm{H} \mid \mathrm{E}_{i}\right) \mathrm{C}\left(\mathrm{H} \mid \tilde{\mathrm{E}}_{j}\right)\right)}, \text { if } \mathrm{DLT} \geqq 0 \\
\frac{\mathrm{DLT}}{\mathrm{P}(\mathrm{H})\left(1+\mathrm{C}\left(\mathrm{H} \mid \mathrm{E}_{i}\right) \mathrm{C}\left(\mathrm{H} \mid \tilde{\mathrm{E}}_{j}\right)\right)}, \text { if } \mathrm{DLT}<0
\end{array}\right.
$$

where,

$$
\begin{aligned}
\mathrm{DLT}= & \mathrm{P}(\tilde{\mathrm{H}}) \mathrm{C}\left(\mathrm{H} \mid \mathrm{E}_{i}\right)+\mathrm{P}(\mathrm{H}) \mathrm{C}\left(\mathrm{H} \mid \tilde{\mathrm{E}}_{j}\right)+ \\
& (\mathrm{P}(\tilde{\mathrm{H}})-\mathrm{P}(\mathrm{H})) \mathrm{C}\left(\mathrm{H} \mid \mathrm{E}_{i}\right) \mathrm{C}\left(\mathrm{H} \mid \tilde{\mathrm{E}}_{j}\right)
\end{aligned}
$$

Usually, the events suggesting the existence of mineral deposits are exceptional, that is $\mathrm{P}(\mathrm{H})<\langle 1$, hence $\mathrm{Eq} .(11) \mathrm{b}$ can be replaced with an approximate one without the a priori probability,

$$
\mathrm{C}\left(\mathrm{H} \mid \tilde{\mathrm{E}}_{i} \tilde{\mathrm{E}}_{j}\right)=\mathrm{C}\left(\mathrm{H} \mid \tilde{\mathrm{E}}_{i}\right)+\mathrm{C}\left(\mathrm{H} \mid \tilde{\mathrm{E}}_{j}\right)+\mathrm{C}\left(\mathrm{H} \mid \tilde{\mathrm{E}}_{i}\right) \mathrm{C}\left(\mathrm{H} \mid \tilde{\mathrm{E}}_{j}\right)
$$

The approximation is illustrated in Figure 2(c), (d). Figure 2(a), (b) show $\mathrm{C}\left(\mathrm{H} \mid \mathrm{E}_{i} \mathrm{E}_{j}\right)$ as a function of $\mathrm{C}\left(\mathrm{H} \mid \mathrm{E}_{j}\right)$ given $\mathrm{P}(\mathrm{H})$ for a fixed value of $\mathrm{C}\left(\mathrm{H} \mid \mathrm{E}_{i}\right)$. It indicates that $\mathrm{C}\left(\mathrm{H} \mid \mathrm{E}_{i} \mathrm{E}_{j}\right)$ is not too sensitive to $\mathrm{P}(\mathrm{H})$. The differences of the confirmation factor, $\mathrm{C}\left(\mathrm{H} \mid \mathrm{E}_{i} \mathrm{E}_{j}\right)$, in light of $\mathrm{P}(\mathrm{H})$ varying between 0.05 to 0.5 , from $\mathrm{C}\left(\mathrm{H} \mid \mathrm{E}_{i} \mathrm{E}_{j}\right)$, given $\mathrm{P}(\mathrm{H})=0.1$, are mostly within 0.1 and not over 0.15 . To perform aggregate updating by Eq.11(c), a good estimate of $\mathrm{P}(\mathrm{H})$ is required.

It is clear that the definition of the confirmation factor $\mathrm{C}$ (.) in our new form of Bayesian model is similar to the certainty factor CF (.) in the MYCIN model, but in the MYCIN model there is no knowledge about the effect of absence of evidence which is denoted in our model by $\mathrm{C}(\mathrm{H} \mid \tilde{\mathrm{E}})$. The uncertainty updating formulae are also different. Our Equations $11 a, b, c$ are the precise formulae derived from classical probability theory about conditionally independent events.

When the types of evidence $\mathrm{E}_{i}, \mathrm{E}_{j}$ are also uncertain, we should first calculate $\mathrm{C}\left(\mathrm{H} \mid \mathrm{E}_{k}{ }^{\prime}\right), k=i, j$, by Eq.(7), and choose one of the Equations (11a,b,c) in light of the sign of $\mathrm{C}\left(\mathrm{H} \mid \mathrm{E}_{k}{ }^{\prime}\right)$ and calculate $\mathrm{C}\left(\mathrm{H} \mid \mathrm{E}_{i}{ }^{\prime} \mathrm{E}_{j}{ }^{\prime}\right)$ by replacing $\mathrm{C}\left(\mathrm{H} \mid \mathrm{E}_{k}\right)$ or $\mathrm{C}\left(\mathrm{H} \mid \tilde{\mathrm{E}}_{k}\right)$ by $\mathrm{C}\left(\mathrm{H} \mid \mathrm{E}_{k}{ }^{\prime}\right)$.

Simple generalized solutions for the aggregate updating of uncertainty due to dependent evidence is still not found. We would like to devise an empirical process as follows.

Suppose we have $\mathrm{E}_{j}$ ' given $\mathrm{E}_{i}{ }^{\prime}$, the contribution of $\mathrm{E}_{j}{ }^{\prime}$ to the uncertainty of the hypothesis $\mathrm{H}$, while $\mathrm{E}_{j}{ }^{\prime}$ is conditionally independent of $\mathrm{E}_{i}{ }^{\prime}$, can be measured by

$\mathrm{D}_{i}\left(\mathrm{E}_{j}^{\prime}\right)=\mathrm{C}\left(\mathrm{H} \mid \mathrm{E}_{i}^{\prime} \mathrm{E}_{j}^{\prime}\right)-\mathrm{C}\left(\mathrm{H} \mid \mathrm{E}_{i}^{\prime}\right)$

If $\mathrm{E}_{j}{ }^{\prime}$ depends on $\mathrm{E}_{i}$, because we assumed previously that all pieces of evidence are favorable to their hypothesis, $\mathrm{E}_{j}^{\prime}$ generally is positively correlated with $\mathrm{E}_{i}$, and the contribution to $\mathrm{H}$ of the presence of dependent evidence $\mathrm{E}_{j}{ }^{\prime}$ given $\mathrm{E}_{i}{ }^{\prime}$ should be less than the contribution of $\mathrm{E}_{j}^{\prime}$ independent of $\mathrm{E}_{i}$. By intuition and mathematical proof, $\mathrm{D}_{i}\left(\mathrm{E}_{j}{ }^{\prime}\right)$ is a monotonously increasing function of $\mathrm{C}\left(\mathrm{H} \mid \mathrm{E}_{j}{ }^{\prime}\right)$, so the decrease of the contribution $\mathrm{D}_{i}\left(\mathrm{E}_{j}{ }^{\prime}\right)$ due to the dependency of $\mathrm{E}_{j}{ }^{\prime}$ on $\mathrm{E}_{i}{ }^{\prime}$ could be emulated by replacing $\mathrm{C}\left(\mathrm{H} \mid \mathrm{E}_{j}{ }^{\prime}\right)$ with an effective confirmation factor $\mathrm{C}_{e i}\left(\mathrm{H} \mid \mathrm{E}_{j}{ }^{\prime}\right)$ which is weaker than $\mathrm{C}\left(\mathrm{H} \mid \mathrm{E}_{j}{ }^{\prime}\right)$ but is regarded as a confirmation factor of an evidence equivalent to $E_{j}$ and conditionally independent of $\mathrm{E}_{i}$. Define the effective confirmation factor $\mathrm{C}_{e i}\left(\mathrm{H} \mid \mathrm{E}_{j}{ }^{\prime}\right)$ as

$$
\mathrm{C}_{e i}\left(\mathrm{H} \mid \mathrm{E}_{j}^{\prime}\right)=\mathrm{C}\left(\mathrm{H} \mid \mathrm{E}_{j}^{\prime}\right)\left(1-r_{i j}\right)
$$


(a)

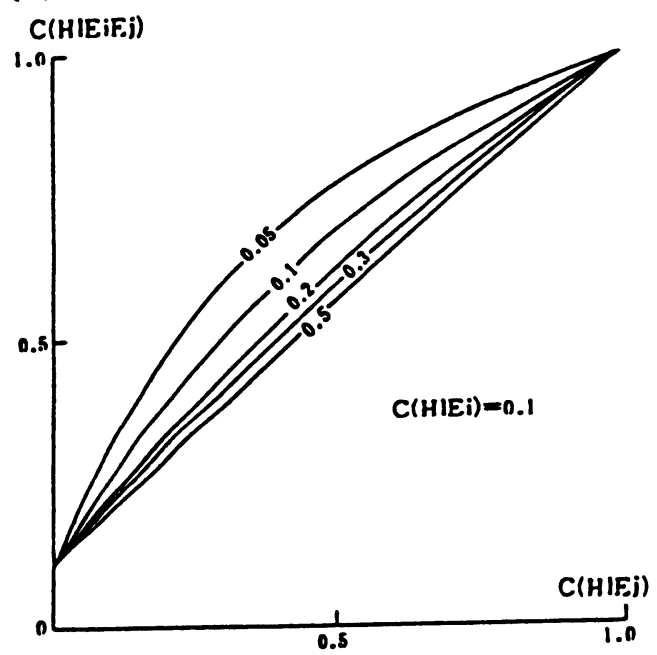

(c)

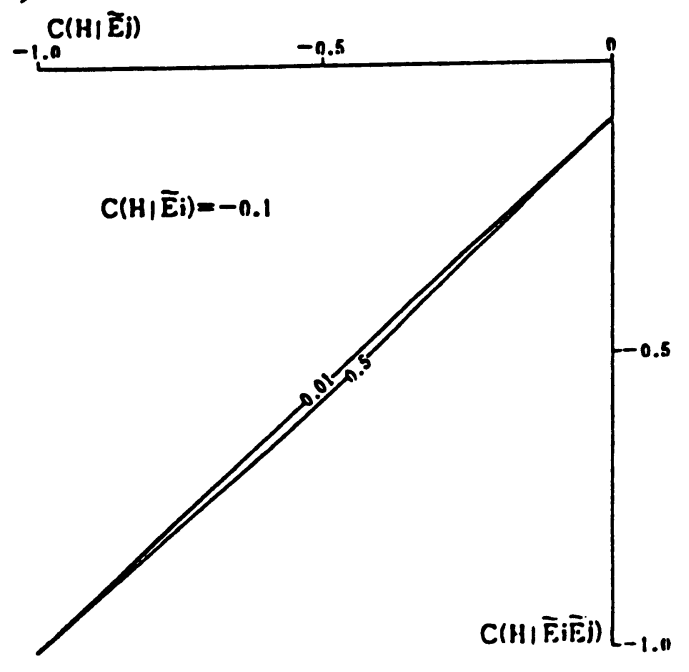

(b)

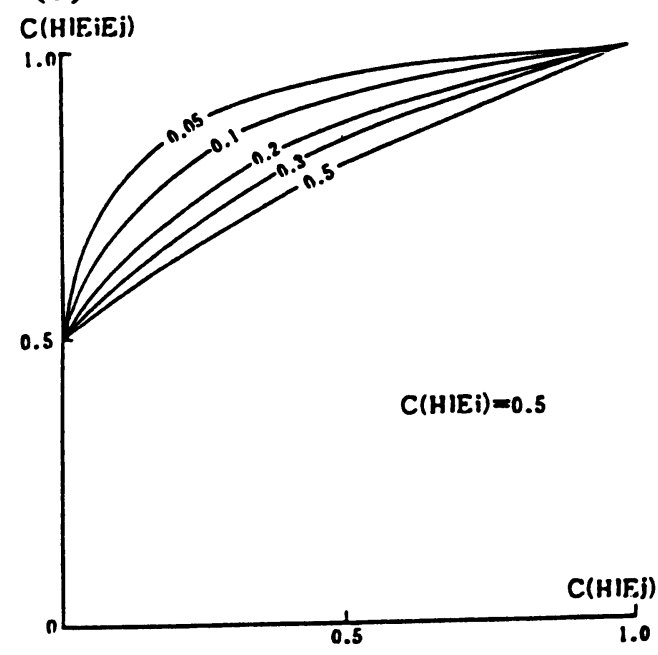

(d)

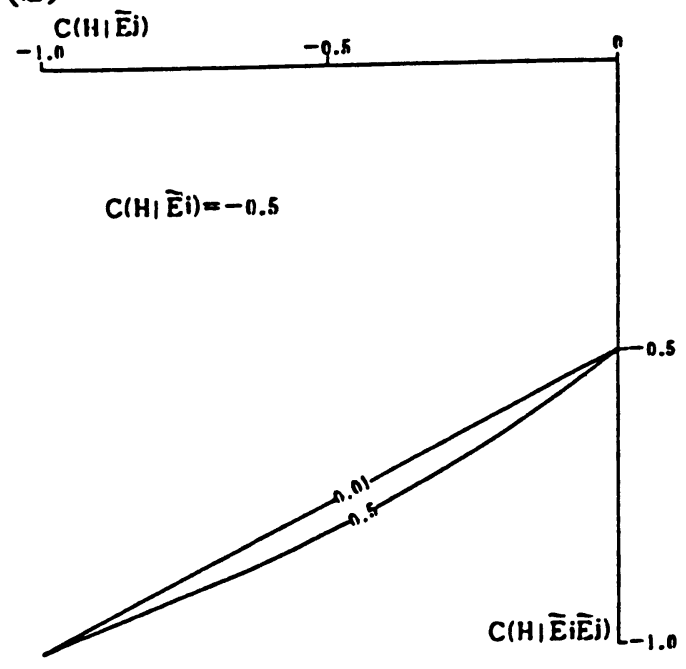

Fig. 2. $C\left(H \mid E_{i} E_{j}\right)$ as a function of $C\left(H \mid E_{j}\right)$ given $P(H)$ for fixed value of $C\left(H \mid E_{i}\right)$, numbers in curves are the values of $\mathrm{P}(\mathrm{H})$

When $E_{j}^{\prime}$ is completely dependent on $E_{i}^{\prime}$, the presence of $\mathrm{E}_{j}^{\prime}$ does not add any new information to $\mathrm{H}$ and $\mathrm{C}_{e i}\left(\mathrm{H} \mid \mathrm{E}_{j}{ }^{\prime}\right)=0$, corresponding to $r_{i j}=1$. In contrast, $r_{i j}=0$ when $\mathrm{E}_{i}^{\prime}$ is conditionally independent of $E_{j}^{\prime}$. The parameter $r_{i j}$ is called a deduction rate of $\mathrm{E}_{j}$ 's information in light of the occurrence of $\mathrm{E}_{i}$. It is very interesting that if $r_{i j}$ is negative or great than 1 , it will reflect the rules of the previously stated Case $\mathrm{A}$ and Case B respectively. This means that $r_{i j}$ is not the same as a correlation coefficient.

If $\mathrm{E}_{i}^{\prime}$ occurs with an uncertainty of $\mathrm{C}\left(\mathrm{E}_{i} \mid \mathrm{E}_{i}{ }^{\prime}\right)$, then the definition formula (12a) changes into

$$
\mathrm{C}_{e i}\left(\mathrm{H} \mid \mathrm{E}_{j}^{\prime}\right)=\mathrm{C}\left(\mathrm{H} \mid \mathrm{E}_{j}{ }^{\prime}\right)\left(1-r_{i j}\left|\mathrm{C}\left(\mathrm{E}_{i} \mid \mathrm{E}_{i}^{\prime}\right)\right|\right)
$$

Similarly, we define the effective confirmation factor of $\mathrm{E}_{i}^{\prime}$ given $\mathrm{E}_{j}^{\prime}$ as:

$$
\mathrm{C}_{e j}\left(\mathrm{H} \mid \mathrm{E}_{i}^{\prime}\right)=\mathrm{C}\left(\mathrm{H} \mid \mathrm{E}_{i}{ }^{\prime}\right)\left(1-r_{j i}\left|\mathrm{C}\left(\mathrm{E}_{j} \mid \mathrm{E}_{j}{ }^{\prime}\right)\right|\right)
$$

where $r_{j i}$ is the deduction rate of $\mathrm{E}_{i}$ 's information in light of the occurrence of $\mathrm{E}_{j}{ }^{\prime} \cdot r_{j i}$ is not required to be the same as $r_{i j}$. Obviously, $r_{i i}=1$.

For aggregate updating of uncertainty due to more than two pieces of evidence $\left\{\mathrm{E}_{i} \mid i=1,2, \cdots, \boldsymbol{n}\right\}$, the effective confirmation factor regarding the evidence $\mathrm{E}_{1}$ ' given $\mathrm{E}_{1}, \mathrm{E}_{2}, \ldots, \mathrm{E}_{i}^{\prime}$ is defined as

$\mathrm{C}_{e 1,2, \ldots, i}\left(\mathrm{H} \mid \mathrm{E}_{1}{ }^{\prime}\right)=\mathrm{C}\left(\mathrm{H} \mid \mathrm{E}_{1}{ }^{\prime}\right) \prod_{j=1}^{i}\left(1-r_{j 1}\left|\mathrm{C}\left(\mathrm{E}_{j} \mid \mathrm{E}_{j}^{\prime}\right)\right|\right)$

$r_{j 1}^{\prime}= \begin{cases}r_{11}, & \text { if } j=1 \\ r_{j 1} \prod_{h=1}^{-1}\left(1-r_{h j}^{\prime}\left|\mathrm{C}\left(\mathrm{E}_{h} \mid \mathrm{E}_{h}{ }^{\prime}\right)\right|\right), & \text { if } j>1\end{cases}$

where the $\left\{r_{j 1}\right\}$ form a matrix of deduction rates of the contribution to $\mathrm{H}$ by evidence $\mathrm{E}_{1}{ }^{\prime}$ in light of the previous presence of evidence $\mathrm{E}_{j}$ '.

The process of aggregate uncertainty updating due to dependent evidence can be described as follows.

(1) Calculate $\mathrm{C}\left(\mathrm{H} \mid \mathrm{E}_{j}\right), \quad j=1,2, \quad \cdots, n$, from $\mathrm{C}\left(\mathrm{E}_{j} \mid \mathrm{E}_{j}{ }^{\prime}\right), \mathrm{C}\left(\mathrm{H} \mid \mathrm{E}_{j}\right)$ or $\mathrm{C}\left(\mathrm{H} \mid \tilde{E}_{j}\right)$ in light of 
Eq.(7).

(2) Sort the $\mathrm{C}\left(\mathrm{H} \mid \mathrm{E}_{j}{ }^{\prime}\right)$ according to their absolute values and we have $\left\{\mathrm{C}\left(\mathrm{H} \mid \mathrm{E}_{i}{ }^{\prime}\right), i=1,2, \ldots\right.$ $, n\}$.

(3) Calculate $\mathrm{C}_{e 1}\left(\mathrm{H} \mid \mathrm{E}_{2}{ }^{\prime}\right)$, combine it with $\mathrm{C}\left(\mathrm{H} \mid \mathrm{E}_{1}{ }^{\prime}\right)$ into $\mathrm{C}\left(\mathrm{H} \mid \mathrm{E}_{1}{ }^{\prime} \mathrm{E}_{2}{ }^{\prime}\right)$.

(4) let $j=3$.

(5) if $j>n$ then quit, otherwise

(6) Calculate $\mathrm{C}_{e 1,2, \ldots, j-1}\left(\mathrm{H} \mid \mathrm{E}_{j}{ }^{\prime}\right)$ by Eq.(13), combine it with $\mathrm{C}\left(\mathrm{H} \mid \mathrm{E}_{1}^{\prime} \mathrm{E}_{2}^{\prime} \quad \cdots \quad \mathrm{E}_{j-1}^{\prime}\right)$ into $\mathrm{C}\left(\mathrm{H} \mid \mathrm{E}_{1}^{\prime} \mathrm{E}_{2}^{\prime} \ldots . \mathrm{E}_{j}^{\prime}\right)$.

(7) $j=j+1$, go to 5 .

\section{Inversion of the Parameters that Describe the Arcs}

The above knowledge model requires parameters to describe knowledge retrieved from experts. Because we usually may not have enough data for statistical processing, the experts are asked to subjectively estimate the parameters, for example, the values of $\mathrm{C}$ $(\mathrm{H} \mid \mathrm{E})$ and $\mathrm{C}(\mathrm{H} \mid \tilde{\mathrm{E}})$ of above Bayesian model, and the prior probabilities of geological events. The meaning of the confirmation factor is easy for geological experts to handle but the $a$ prior probability and deduction rate $r_{i j}$ are not.

The deduction rate $r_{i j}$ is not the same as a correlation coefficient. We suggest the following process to determine the deduction rate by inversion.

(1) Domain experts assign $\mathrm{C}\left(\mathrm{H} \mid \mathrm{E}_{i} \mathrm{E}_{j}\right)$, the Confirmation factor, due to the coexistence of $\mathrm{E}_{i}$ and $\mathrm{E}_{j}$.

(2) Calculate $\mathrm{C}_{e i}\left(\mathrm{H} \mid \mathrm{E}_{j}\right)$ in light of $\mathrm{Eq} .(11 \mathrm{a})$ from $\mathrm{C}\left(\mathrm{H} \mid \mathrm{E}_{i} \mathrm{E}_{j}\right)$, and $\mathrm{C}\left(\mathrm{H} \mid \mathrm{E}_{i}\right)$.

$$
\mathrm{C}_{e i}\left(\mathrm{H} \mid \mathrm{E}_{j}\right)=\frac{\mathrm{P}(\mathrm{H})\left(\mathrm{C}\left(\mathrm{H} \mid \mathrm{E}_{i} \mathrm{E}_{j}\right)-\mathrm{C}\left(\mathrm{H} \mid \mathrm{E}_{i}\right)\right)}{\mathrm{C}\left(\mathrm{H} \mid \mathrm{E}_{i}\right) \mathrm{P}(\tilde{\mathrm{H}})\left(1-\mathrm{C}\left(\mathrm{H} \mid \mathrm{E}_{i} \mathrm{E}_{j}\right)\right)+\mathrm{P}(\mathrm{H})\left(1-\mathrm{C}\left(\mathrm{H} \mid \mathrm{E}_{i}\right)\right)}
$$

(3) Calculate $r_{i j}$ according to Eq.(12) from $\mathrm{C}_{e i}\left(\mathrm{H} \mid \mathrm{E}_{j}\right)$ and $\mathrm{C}\left(\mathrm{H} \mid \mathrm{E}_{j}\right)$, $r_{i j}=1-\mathrm{C}_{e i}\left(\mathrm{H} \mid \mathrm{E}_{j}\right) / \mathrm{C}\left(\mathrm{H} \mid \mathrm{E}_{j}\right)$, fill it in the deduction rate matrix $\left\{r_{i j}\right\}$.

(4) Calculate $r_{j i}$ by the same routine and fill it in the matrix.

(5) repeat step (1) (4) until all of the entries of $\left\{r_{i j}\right\}$ are filled.

To determine the prior probabilities of nodes, the prior probabilities of input nodes should be first assessed by the experts, then prior probabilities of their parent nodes could be determined in light of Eq.(10) from $\mathrm{C}(\mathrm{H} \mid \mathrm{E})$ and $\mathrm{C}(\mathrm{H} \mid \tilde{\mathrm{E}})$ and $\mathrm{O}(\mathrm{E})$. The prior probability of a node calculated from the different immediate descendant nodes using Eq.(10) should be the same. Therefore it provides a restraint to the experts for checking the consistency of the pa- rameters they have assigned. It is interesting that by the use of Eq.(10) one is offered the possibility to choose another type of input information. That is, if experts are confident of the prior probabilities $\mathrm{P}(\mathrm{H})$ and $\mathrm{P}(\mathrm{E})$ they assessed, $\mathrm{C}(\mathrm{H} \mid \tilde{\mathrm{E}})$ can be evaluated from $\mathrm{C}(\mathrm{H} \mid \mathrm{E})$, and vice versa.

\section{A Prototype System Expressing the Above Ideas}

The above ideas on knowledge representation are examined in a prototype system. Figure 3 shows the structure of the knowledge base.

The following uncertainty updating models of compound propositions are included in the preset inference modules.

1. BYS, our new form of Bayesian model ;

2. MYC, the MYCIN certainty factor model :

$$
\mathrm{CF}\left(\mathrm{H} \mid \mathrm{E}_{i} \mathrm{E}_{j}\right)=\left\{\begin{array}{c}
\mathrm{CF}\left(\mathrm{H} \mid \mathrm{E}_{i}\right)+\mathrm{CF}\left(\mathrm{H} \mid \mathrm{E}_{j}\right)-\mathrm{CF}\left(\mathrm{H} \mid \mathrm{E}_{i}\right) \mathrm{CF}\left(\mathrm{H} \mid \mathrm{E}_{j}\right), \\
\text { if } \mathrm{CF}\left(\mathrm{H} \mid \mathrm{E}_{i}\right)>0 \text { and } \mathrm{CF}\left(\mathrm{H} \mid \mathrm{E}_{j}\right)>0 \\
\mathrm{CF}\left(\mathrm{H} \mid \mathrm{E}_{i}\right)+\mathrm{CF}\left(\mathrm{H} \mid \mathrm{E}_{j}\right)+\mathrm{CF}\left(\mathrm{H} \mid \mathrm{E}_{i}\right) \mathrm{CF}\left(\mathrm{H} \mid \mathrm{E}_{j}\right), \\
\text { if } \mathrm{CF}\left(\mathrm{H} \mid \mathrm{E}_{i}\right)<0 \text { and } \mathrm{CF}(\mathrm{H} \mid \mathrm{E})<0, \\
\frac{\mathrm{CF}\left(\mathrm{H} \mid \mathrm{E}_{i}\right)+\mathrm{CF}\left(\mathrm{H} \mid \mathrm{E}_{j}\right)}{1-\min \left(\mathrm{CF}\left(\mathrm{H} \mid \mathrm{E}_{i}\right), \mathrm{CF}\left(\mathrm{H} \mid \mathrm{E}_{j}\right)\right)}, \\
\text { if } \mathrm{CF}\left(\mathrm{H} \mid \mathrm{E}_{i}\right) \mathrm{CF}\left(\mathrm{H} \mid \mathrm{E}_{j}\right)<0,
\end{array}\right.
$$

3. D-S-SUM, the Dempster's rule.

4. MIN-OR, the disjunction under minimum correlation, $\mathrm{P}\left(\mathrm{H} \mid \mathrm{E}_{i} \mathrm{E}_{j}\right)=\min \left(1, \mathrm{P}\left(\mathrm{H} \mid \mathrm{E}_{i}\right)+\mathrm{P}\left(\mathrm{H} \mid \mathrm{E}_{j}\right)\right) ;$

5. INDEPENDENT-OR, $\mathrm{P}\left(\mathrm{H} \mid \mathrm{E}_{i} \mathrm{E}_{j}\right)=\mathrm{P}\left(\mathrm{H} \mid \mathrm{E}_{i}\right)+\mathrm{P}\left(\mathrm{H} \mid \mathrm{E}_{j}\right)-\mathrm{P}\left(\mathrm{H} \mid \mathrm{E}_{i}\right) \mathrm{P}\left(\mathrm{H} \mid \mathrm{E}_{j}\right)$;

6. MAX-OR, the disjunction under maximum correlation, corresponding to the operation of Fuzzy set theory. $\mathrm{P}\left(\mathrm{H} \mid \mathrm{E}_{i} \mathrm{E}_{j}\right)=\max \left(\mathrm{P}\left(\mathrm{H} \mid \mathrm{E}_{i}\right), \mathrm{P}\left(\mathrm{H} \mid \mathrm{E}_{j}\right)\right)$;

7. MIN-AND, conjunction under minimum correlation,

$\mathrm{P}\left(\mathrm{H} \mid \mathrm{E}_{i} \mathrm{E}_{j}\right)=\max \left(0, \mathrm{P}\left(\mathrm{H} \mid \mathrm{E}_{i}\right)+\mathrm{P}\left(\mathrm{H} \mid \mathrm{E}_{j}\right)-1\right) ;$

8. INDEPENDENT-AND,

$\mathrm{P}\left(\mathrm{H} \mid \mathrm{E}_{i} \mathrm{E}_{j}\right)=\mathrm{P}\left(\mathrm{H} \mid \mathrm{E}_{i}\right) \mathrm{P}\left(\mathrm{H} \mid \mathrm{E}_{j}\right)$;

9. MAX-AND, the conjunction under maximum correlation, corresponding to the operation of Fuzzy set theory $\mathrm{P}\left(\mathrm{H} \mid \mathrm{E}_{i} \mathrm{E}_{j}\right)=\min \left(\mathrm{P}\left(\mathrm{H} \mid \mathrm{E}_{i}\right), \mathrm{P}\left(\mathrm{H} \mid \mathrm{E}_{j}\right)\right)$;

The name of the selected model followed by necessary parameters is put into the inference information list as part of the attributes of hypotheses in the knowledge base.

The approach of aggregate updating of uncertainty in light of dependent evidence is tested in this system and shows good performance. Here we have an example. We consider a model of a supergene deposit. The favorable climate is a necessary condition for this kind of mineral deposit. Before reaching the con- 
clusion that climate in the target area is favorable, we shall consider five pieces of evidence:
(1) soil type,
(2) vegetation development,
(3) average annual rainfall,
(4) average annual temperature,
(5) latitude.

Table 1 is the table of expert-assigned confirmation factors of FC (Favorable Climate) in light of a single piece of evidence or two pieces of evidence. We note that annual rainfall and temperature are the most important. Latitude provides general information, but make little difference after we know annual rainfall and temperature. Vegetation development and soil type also provide information. Mediumly developed vegetation indicates that climate is favorable to rockweathering and red soil means that the weathering intensity is strong enough.

The last column of Table 2 shows the calculated confirmation factors of FC under the conditional independence assumption. The aggregate confirmation factors are too close to 1 . They increase too fast because the strong correlation among pieces of evidence are improperly ignored. The column next to the last shows the calculated aggregate confirmation factors in light of dependent evidence. They are very much closer to the values experts assigned.

Table 3 shows the deduction rates of evidence in light of preexistence of other evidence. The deduction rates are too big to ignore in aggregate updating of confirmation factors.

\section{Conclusion}

There has been controversy on knowledge representation, especially over management of uncertainty. Our opinion about describing experts' knowledge by utilizing the form experts use does not mean duplicating all features of human judgment, including biases which may lead to some results against normative theory. More studies are necessary to explore res-

Table 1. Expert-assigned confirmation factors of FC

\begin{tabular}{|c|c|c|c|c|c|c|}
\hline \multirow{2}{*}{\multicolumn{2}{|c|}{$C\left(H / E_{i} E_{j}\right)$ CA }} & VD & ST & AAR & $\mathrm{AAT}$ & LÁT \\
\hline & & 0.2 & 0.2 & 0.4 & 0.4 & 0.4 \\
\hline VD & 0.2 & 0.2 & 0.3 & 0.55 & 0.55 & 0.55 \\
\hline ST & 0.2 & 0.3 & 0.2 & 0.55 & 0.55 & 0.55 \\
\hline AAR & 0.4 & 0.55 & 0.55 & 0.4 & 0.7 & 0.55 \\
\hline AAT & 0.4 & 0.55 & 0.55 & 0.7 & 0.4 & 0.55 \\
\hline LAT & 0.4 & 0.55 & 0.55 & 0.55 & 0.55 & 0.4 \\
\hline
\end{tabular}

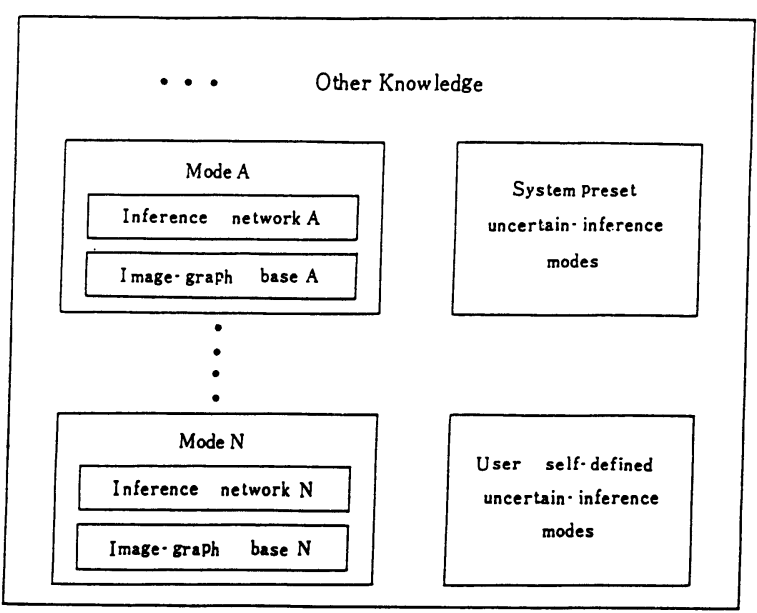

Fig. 3. Structure of knowledge-base

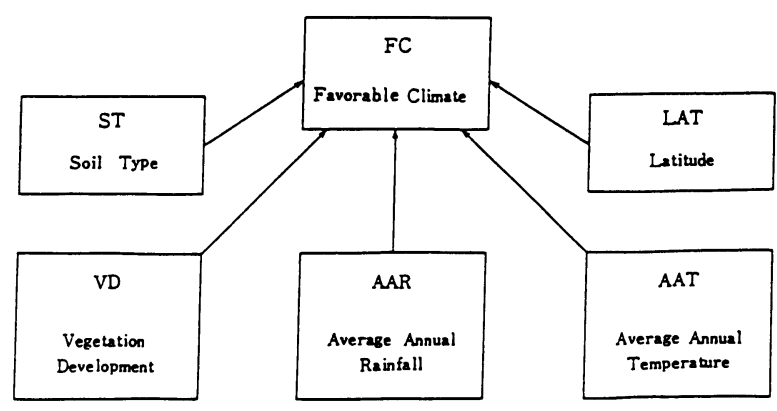

Fig. 4. Network of favorable climate

Table 2. Calculated confirmation factors of FC

\begin{tabular}{|l|c|c|c|}
\hline \multirow{2}{*}{$\begin{array}{c}\text { Confirmation } \\
\text { Factor }\end{array}$} & \multirow{2}{*}{$\begin{array}{c}\text { Expert } \\
\text { Assigned }\end{array}$} & \multicolumn{2}{|c|}{ Calculated } \\
\cline { 3 - 4 } & Dep. & Indep. \\
\hline C(FC|VD,ST) & 0.3 & 0.3 & 0.529 \\
\hline C(FC|VD,AAR) & 0.55 & 0.55 & 0.721 \\
\hline C(FC|LAT,ST,VD) & 0.6 & 0.65 & 0.903 \\
\hline C(FC|AAR,AAT,LAT) & 0.7 & 0.765 & 0.978 \\
\hline C(FC|AAR,AAT,LAT,ST) & 0.8 & 0.816 & 0.994 \\
\hline
\end{tabular}

traint between values obtained from domain experts to guarantee the consistency of ore deposit models and to prevent biases, to compare the behavior of different approaches and to examine carefully in which situations they work well.

We devise an algorithm as the first order approximate expression of uncertainty updating due to dependent evidence. Such a technique is not exact. But because the conditional probabilities reflect judgmental (and thus highly subjective) knowledge, a rigorous application of probability theory will not necessarily produce accurate cumulative probabilities 
either. The major advantage of the proposed method is that it explicitly expresses the degree of dependence and can be easily used in knowledge acquisition and programming. There are some new approaches for this issue that have emerged recently. G. Pearl developed a dependency graph, or Bayesian net (Pearl, 1987) and D. Driankov presented an algorithm of calculating high order joint probabilities to encode dependence from the least possible number of a priori and conditional probabilities obtained from experts (Driankov, 1989). Considerable work needs to be done before these approaches can be applied to a practical system in geological exploration.

Acknowledgment : We gratefully thank Dr. F. Zheng and Ms. F. Lin for their helpful discussion with us on the issue this paper covered. We would also like to thank the anonymous reveiwers for their comments which substantially improved the quality of the manuscript. This work is supported by the Ministry of Geology and Mineral Resources under the grant of the project of "Mineral Resource and Geological Environment Expert Systems".

\section{References}

Cui, W. and Blockly, D. I. (1990) Interval probability theory for evidential support. International Journal of Intelligent Systems, 5, 183-192.

Driankov, D. (1989) Inference with consistent probabilities in expert system. International Journal of Intelligence Systems, 4, 1-21.

Duda R.O. et al.(1976) Subjective Bayesian Methods for rule-based inference systems. Proceedings of National Conference (AFIPS Conference Proceedings) , New York, 45, 1075-1082.

Duda R.O. et al. (1979) A computer-based consultant for mineral exploration. Final Report of SRI project 6415, SRI International, Menlo Park, Califonia.

Fagin, R. and Halpern, J. Y. (1989) Uncertainty, belief and probability, Proceedings of the 11 th International Joint Conference on Artificial Intelligence (IJCAI'89 Proceediogs), Detroit, Michigan, 11611167.

Henrion, M. (1986) Uncertainty in artificial intelligence: is probability epistemologically and heuristically adequate? : In Expert Judgment and Expert Systems, (Mumpower, J. L. et al. eds.) SpringerVerlag, 105-129.
Table 3. Deduction rates of evidence of FC

\begin{tabular}{|c|c|c|c|c|c|}
\hline$E_{j} E_{i}$ & $V D$ & $S T$ & AAR & AAT & LAT \\
\hline VD & 1.0 & 0.757 & 0.662 & 0.662 & 0.662 \\
\hline$S T$ & 0.757 & 1.0 & 0.662 & 0.662 & 0.662 \\
\hline AAR & 0.457 & 0.457 & 1.0 & 0.554 & 0.831 \\
\hline AAT & 0.457 & 0.457 & 0.554 & 1.0 & 0.831 \\
\hline LAT & 0.457 & 0.457 & 0.831 & 0.831 & 1.0 \\
\hline
\end{tabular}

Horvitz,F. and Hecherman, D. (1986) The inconsistent use of measures of certainty in artificial intelligence Research. : In Uncertainty in Artificial Intelligence (Kanal, L. K. and Lemmer, J. F. eds.), Elsevier Science Publishers B. V., North-Holland, 137-151.

Kyburg, J. (1987) Bayesian and Non-Bayesian evidential updating. Artificial Intelligence, 31, 271-293.

Lee, C. H. (1988) A comparison of two evidential reasoning schemes. Artificial Intelligence, 35, 127-134.

Pearl, J. (1987) Probabilistic reasoning using graphs. : In Uncertainty in Knowledge-Based Systems, Berlin, Springer, 200-202.

Shafer, G. (1976) A mathematical theory of evidence. Princeton University Press.

Shafer, G. (1981) Jeffrey's rule of conditioning, Philos. Sci., 48, 337-362.

Shafer, G. (1987) Belief functions and possibility measures, : In The Analysis of Fuzzy information (Bizdek, J. C. eds.), 1, CRC Press, 51-84.

Shortliffe, E. H. and Buchman, B. G. (1984) A model of inexact reasoning in medicine. : In Rule-based expert systems: the MYCIN experiments of the Stanford heuristic programming project (Buchanan, B. G. and Shortliffe, E. H. eds.), Addison-Wesley Publishing Company, 233-262.

Victor, L. Y. et al. (1984) An evaluation of MYCIN's advice, : In Rule-based expert systems: the MYCIN experiments of the Stanford heuristic programming project (Buchanan, B. G. and Shortliffe E. H. eds.), Addison-Wesley Publishing Company, 589-596.

Zadeh, L.A. (1984) Making computers think like people. IEEE Spectrum, August, 26-32. 


\section{要旨}

地質学的探查のための知識表現 : 尅宣志・史大年

地質学的探查における実用的エキスパートシステムを構築するためには, 専門家の知識をいかに表現 するかが重要な課題である. 専門家の知識における不確実さを定量化する従来の試みとして，マイシン の確信度, ファジイ集合論, プロスペクターの準確率的表現, デンプスター・シャファー論の信頼関数 がある. 本研究では, これらの単一推論モデルの代わりに, 合成・不確実・推論モデルという概念を導 入した。 その結果, 知識のネットワーク（Fig. 1)に対し, 式 (1) 功式 (11) に示す理論展開を行う [C

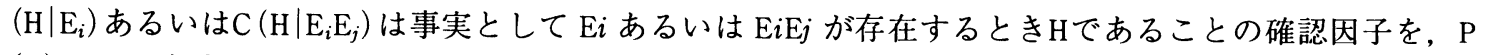
(H) は $\mathrm{H}$ が起きる確率を表す]ことにより， $\mathrm{C}\left(\mathrm{H} \mid \mathrm{E}_{i}\right)$ と $\mathrm{C}\left(\mathrm{H} \mid \mathrm{E}_{i} \mathrm{E}_{j}\right)$ の関係が得られる (Fig. 2). 以上の考 え方を風化残留型鉱床の生成に適した気候の評価問題に適用した(Fig. 3)，このときの評価で考慮した 事実は, 植生の発達度 (VD), 土壤の型 (ST), 年平均降雨量 (AAR), 年平均温度 (AAT), 緯度 (LAT) で ある (Fig. 4). 今回の事例研究では, 以上の事実が適正気候を示唆する場合の確認因子の值を, 専門家 から聞く(Table 1) とともに, それらが従属関係にある場合と独立関係にある場合について計算し(Table 2), 最後にある事実の確認因子の值が他の事実が存在するときどの程度減少するかを求めた (Table 3). キーワード：人工知能, エキスパートシステム, 知識表現, 不確定推論, 従属現象, 確実性係数, 地質調査, 浅成鉱床 